\title{
Functional Distribution of Bacterial Community under Different Land Use Patterns Based on FaProTax Function Prediction
}

\author{
Shichu Liang ${ }^{1 \#}$, Jiaojiao Deng ${ }^{2 \#}$, Yong Jiang ${ }^{1}$, Shijun $\mathrm{Wu}^{2}$, \\ Yongbin $\mathrm{Zhou}^{2}$,Wenxu $\mathrm{Zhu}^{2 *}$ \\ ${ }^{1}$ Laboratory of Ecology of Rare and Endangered Species and Environmental Protection (Guangxi Normal University), \\ Ministry of Education, Guilin, Guangxi, China \\ ${ }^{2}$ College of Forestry, Shenyang Agriculture University, Shenyang, China
}

Received: 14 November 2018

Accepted: 14 April 2019

\begin{abstract}
Soil microorganisms play an important role in biogeochemical cycling. The bacterial community functional community profiles across different land use types in the mountainous region of eastern Liaoning Province, China, such as natural secondary forest (Quercus mongolica (QM)), shrub wood (SW), coniferous planation (Larix gmelini (LG), and Pinus koraiensis (PK)), and agricultural land (Zea mays (ZM)) were evaluated using high-throughput sequencing of the bacterial 16S rDNA gene, and predicted based on the FaProTax database. Bacterial functional groups varied across samples under different land use patterns. A total of 53 functional groups were acquired using FaProTaxin accordance with the classification annotation results of 16S rDNA sequences. These functional groups contained 5809 OTUs, accounting for $66.25 \%$ of all OTUs. The dominant functions were chemoheterotrophs and aerobicchemoheterotrophy with average relative abundance of $21.69 \%$ and $21.01 \%$, respectively. In addition, we detected 15 and 12 ecological function groups related to the carbon and nitrogen cycles, respectively. The bacterial functional groups of ZM were clearly separated from those of PK, LG, QM, and SW, indicating that functional groups of agriculture soil differed from those of forest soils. Furthermore, the bacterial functional groups of LG and PK were obviously separated from those of QM and SW, suggesting that functional groups of broad leaf forest differed from those of coniferous forests. Also, we analyzed the main factors that influence soil bacterial community functional groups under different land use patterns. It was found that soil environmental conditions, especially soil $\mathrm{pH}$, $\mathrm{NH}_{4}^{+}-\mathrm{N}$, and $\mathrm{NO}_{3}^{-}-\mathrm{N}$ content,and strongly influenced the distribution of functional groups about carbon
\end{abstract}

\#Authors who contributed equally to this work.

*e-mail: zhuwenxu.315@163.com 
and nitrogen cycles in bacterial communities. It is of great significance to provide a scientific basis for the sustainable utilization of soil in northeastern China.

Keywords: forest soils, agriculture soil, FaProTax function prediction, carbon cycles, nitrogen cycles

\section{Introduction}

Global climate, biodiversity and ecosystem services are strongly influenced by land-use conversion [1-2]. And the rational land use types play an important role in improving soil structure and promoting regional ecological restoration. In recent years, an increasing number of natural forests have been converted to planted forests and arable landin order to fulfill needs for timber, agricultural production, and other economic forest products [3-5]. So far, more than $38 \%$ of natural landscapes around the world have been converted to managed systems [6]. The conversion of forests to farmland has been studied most frequently worldwide, with more research in tropical environments [7], which not only bring about great challenges for maintaining forest ecosystems, but also have a potential impact on terrestrial ecosystems. It has long been recognized that changes in land use types alter a soil's physical and chemical properties, the structure and function of an ecosystem, and soil quality [8-9]. Also, land-use change significantly affects the dynamics and stability of soil organic carbon (SOC) and enzyme activities [10]. In addition, land use is a crucial factor affecting soil microbial communities under the same climatic conditions [11-12]. Conversion of forest to cultivated land typically leads to a decline of soil organic matter (SOM) [13], which was linked to decreases in soil microbial biomass and activity [14]. Soil microorganisms, as the most active component of a soil ecosystem, can sensitively reflect the changes of soil ecological environment [15]. Therefore, analyzing soil microbial characteristics is a valuable approach for assessing the effectiveness of different land use types, and to evaluate the suitability of different land use types [7].

Microbial communities are incredibly active and diverse, which drive global biogeochemical cycling, such as $\mathrm{C}$ and $\mathrm{N}$ cycling [16], playing key roles in the terrestrial ecosystem [17], such as maintaining soil structure, conservation of soil fertility, forming and developing of soil, influencing soil ecological processes, and ensuring system stability [18-19]. In addition, soil microbes also play a crucial role in plant growth and crop production [20]. Researchers report that soil microorganisms are very sensitive to environmental stressors, and can respond quickly to the changes of physicochemical conditions, and abiotic and biotic environmental stressors [21]. So, changes in soil microbial community diversity, composition, and function can be used to rapidly reflect soil quality and vegetation changes, and accurately evaluate sustainable ecosystem development of soil [22-23].
Recently, the influence of different land use patterns on soil microbiological indicators has been reported both in China and abroad [24-25]. Surveys targeting the effects of land use change on soil microbial communities have been extensively studied in grassland, jungle, and forest ecosystems, frequently contrasting between natural forests, jungles, and plantations [26,10], natural grassland and agricultural fields [27], forest, grassland and no-till cropping [28]. Overall, changes in land use patterns can significantly affect soil microbial community diversity and composition [29],as well as their metabolic activity [9] - especially between wooded and agricultural soils [30]. In addition, land use change shifts the decomposer community structure and negatively affects litter decomposition [26]. Land use has strong effects on soil microbes, with consequences pertaining to microbial community diversity and composition [31]. However, the ecological function of this variation remains largely unknown. Microbial communities of different functions are involved in various processes of $\mathrm{C}$ and $\mathrm{N}$ cycle and play an important role in maintaining ecosystem stability. Even fewer studies exist targeting soil microbial community function relevant to Cand $\mathrm{N}$ cycling under different land use types. In light of this, it is necessary to deeply study the soil $\mathrm{C}$ and $\mathrm{N}$ process in different land use types, which will help to elucidate the microbiological mechanisms that are related to the nutrient cycling in the land-use change.

Monitoring soil bacterial community function changes in different land use patterns can provide a theoretical basis for the restoration of degraded soil ecosystems and sustainable management of forests. High-throughput sequencing of $16 \mathrm{~S}$ rDNA is a commonly used technique for investigating bacterial community structure [32-34]. With the development of bioinformatics tools and databases [35-36], metabolome-encoded data have been widely used for not only describing the composition of a soil microbial community, but also for predicting the soil microbial community function in various environmental conditions. And many functional prediction software programs have been developed based on 16S rDNA sequencing data, such as PICRUST [37], Tax4Fun [38], FAProTax [35], have been widely used in soil bacterial function prediction [39-40].

In northeastern China, due to the increasing demand for economic demand, part of the secondary forests have been converted into plantation and cultivated land. Although the change in land use pattern has brought about a substantial economic increase, there is a lack of research on changes in soil ecosystems - especially 
soil microbial communities. Our study focused on the changes of the soil bacterial community functional groups under the impacts of different land use types in the mountainous region of Liaodong, including Quercus mongolica, shrub wood, Larixgmelini, Pinuskoraiensis, and Zeamays. Here, soil bacterial community functional groups were analyzed via the functional annotation of prokaryotic taxa (FAPROTAX) database on the basis of experimental literature through $16 \mathrm{~S}$ rDNA highthroughput sequencing. We then explored soil bacterial ecological functional groups related to $\mathrm{C}$ and $\mathrm{N}$ cycles in different land use patterns, and functional groups in correlation with soil environmental factors. Specifically, the following hypotheses were tested: (1) converting broadleaf forests to plantations and farmland decreasing concentrations of total $\mathrm{C}$ and total $\mathrm{N}$; (2) the soil bacterial community functional groups related to $\mathrm{C}$ and $\mathrm{N}$ cycling shows a difference between broadleaf forests, plantations, and farmland; and (3) change in the soil bacterial community functional groups caused by land-use change are linked to changes in soil environment factors. The ultimate objective was to investigate which of these soil environment factors may play a central role in determining the soil microbial function under different land use types. It can provide scientific basis for rational utilization and sustainable management of agricultural and forestry land resources in the region, as well as in northeastern China.

\section{Materials and Methods}

\section{Research Area}

Our research was carried out at the experimental forest farm of the Liaoning Institute of Forest Management, Liaoning Province, China $\left(40^{\circ} 52^{\prime} 31^{\prime \prime} \mathrm{N}-123^{\circ} 56^{\prime} 43^{\prime \prime} \mathrm{E}\right)$, which lies in the hilly land of the mountainous region of eastern Liaoning Province with an average altitude of $645 \mathrm{~m}$. The research area has a typical temperate continental monsoon climate with an annual average temperature of $6.5^{\circ} \mathrm{C}$ and mean annual precipitation of $926.3 \mathrm{~mm}$. The lowest temperature is $-33^{\circ} \mathrm{C}$ and the highest is $32^{\circ} \mathrm{C}$. The soil type is brown soil with soil freezing depth of $150 \mathrm{~cm}$. Due to excessive harvesting and utilization over the past 100 years, the original vegetation has been seriously damaged. A large number of secondary forests have been transformed into Pinus koraiensis and Larix gmelinii plantations due to the increasing demand for timber, some of which were reclaimed as farmland. Land use patterns mainly include natural secondary forests, plantations, and agricultural lands (Zea mays and Glycine max). Prior to the cultivation of Zea mays, the forest vegetation type was shrub wood, whichwas cultivated for 5 years. Field management in the area is extensive, no irrigation measures were used, and harvested corn straw were not returned to the field.

\section{Soil Sample Collection}

In our study, five sites with uniform conditions were selected in July 2017, including Quercus mongolica (QM), shrub wood (SW), Larix gmelini (LG), Pinus koraiensis (PK), and Zea mays (ZM). Soil samples were collected from 3 plots $(20 \mathrm{~m} \times 20 \mathrm{~m})$ as three independent replicates, using a soil auger $(8 \mathrm{~cm}$ in diameter, $10 \mathrm{~cm}$ deep) at $10 \mathrm{~cm}$ depths from each plot. To guarantee the representativeness of soil samples in each forest, "S" multi-point sampling was applied. Soil from 15-20 points were mixed together and placed in sterile plastic bags as a replicate sample from each plot, with marks after the samples had been well mixed, and then samples were stored in ice boxes. Soil samples were well mixed, and screened using $2 \mathrm{~mm}$ sieves to remove residual plant roots and debris. A portion of the prepared soil samples was stored at $-80^{\circ} \mathrm{C}$ for high-throughput sequencing, and the rest was air-dried at room temperature for determining soil chemical characteristics.

\section{Determining Soil Properties}

Soil $\mathrm{pH}$ was measured using a $\mathrm{pH}$ meter after shaking a soil-water $(1: 5 \mathrm{w} / \mathrm{v})$ suspension for $30 \mathrm{~min}$. Soil total carbon $(\mathrm{C})$ and total nitrogen $(\mathrm{N})$ contents were measured with an elemental analyzer (Elementar, Germany). Available nitrogen (N) was determined by the alkali diffusion method. Total phosphorus (P) was measured by spectrophotometry after wet digestion with $\mathrm{HClO}_{4}-\mathrm{H}_{2} \mathrm{SO}_{4}$. Contents of soil $\mathrm{KCl}$ extraction nitrate nitrogen $\left(\mathrm{NO}_{3}^{-}-\mathrm{N}\right)$ and ammonium nitrogen $\left(\mathrm{NH}_{4}{ }^{+} \mathrm{N}\right)$ and were determined using an AA3 (Germany) continuous flow analytical system.

\section{Soil DNA Extraction}

Total genomic DNA was extracted from $0.5 \mathrm{~g}$ of soil using a Fast DNA SPIN extraction kit (MP Biomedicals, Santa Ana, CA, USA), in accordance with the manufacturer's protocol, and stored at $-20^{\circ} \mathrm{C}$ until further analysis. A NanoDrop ND-1000 spectrophotometer (Thermo Fisher Scientific, Waltham, MA, USA) was used to measure the amount of DNA, and the DNA quality was measured using agarose gel electrophoresis.

\section{S rDNA Amplicon Pyrosequencing}

PCR amplification in the bacterial V3-V4 region of 16S rDNA was carriedout using the forward primer $338 \mathrm{~F}$ (5'-ACTCCTACGGGAGGCAGCA-3') and the reverse primer 806R (5'-GGACTACHVGGGTWTCTAAT-3'). The sample-specific 7-bp barcodes were incorporated in the primers for multiplex sequencing. Each of three independent $25 \mu \mathrm{L}$ reactions per DNA sample contained $5 \mu \mathrm{L}$ of Q5 reaction buffer $(5 \times), 5 \mu \mathrm{L}$ of Q5 High-Fidelity GC buffer $(5 \times), 1 \mu \mathrm{L}(10 \mathrm{uM})$ of 
forward primer, $1 \mu \mathrm{L}(10 \mathrm{uM})$ of reverse primer, $2 \mu \mathrm{L}$ $(2.5 \mathrm{mM})$ of dNTPs, $0.25 \mu \mathrm{L}$ of Q5 High-Fidelity DNA Polymerase $(5 \mathrm{U} / \mu \mathrm{l}), 2 \mu \mathrm{L}$ (40-50 ng)of DNA template, and $8.75 \mu \mathrm{L}$ of $\mathrm{ddH}_{2} \mathrm{O}$. Cycling conditions were $98^{\circ} \mathrm{C}$ for $5 \mathrm{~min} ; 25$ cycles of $98^{\circ} \mathrm{C}$ for $15 \mathrm{~s}, 55^{\circ} \mathrm{C}$ for $30 \mathrm{~s}, 72^{\circ} \mathrm{C}$ for $30 \mathrm{~s}$, and $72^{\circ} \mathrm{C}$ for $5 \mathrm{~min}$. Agencourt AMPure Beads (Beckman Coulter, Indianapolis, IN) was used to purify the PCR amplicons, and a PicoGreen dsDNA assay kit (Invitrogen, Carlsbad, CA, USA) was applied to quantify the PCR amplicons. After the individual quantification step, amplicons were pooled in equal amounts and pairend $2 \times 300 \mathrm{bp}$ sequencing was performed using the Illlumina MiSeq platform with a MiSeq Reagent Kit v3 (Shanghai Personal Biotechnology Co., Ltd, Shanghai, China).

\section{FAProTax Function Prediction}

Functional annotation of prokaryotic taxa (FAPROTAX), a database that extrapolates functions of cultured prokaryotes to estimate metabolic or other ecologically relevant functions, is more suitable for the functional annotation and prediction of the biogeochemical cycle (especially the cycle of carbon, hydrogen, nitrogen, phosphorus and sulfur) of environmental samples [35]. The FAPROTAX database based on the current manual collation of culturable bacteriacontains more than 7,600 functional annotations from more than 80 functional groups (e.g., nitrate respiration, methanogenesis, fermentation, plant pathogens, etc.) collected from more than 4,600 prokaryotic microorganisms. Based on the mentioned functional information in the existing microbiology literature, the names of related species in the database are summarized from functional classification and annotation information. When used, read an annotated OTU table of Greengenes or Silva database, match the annotated information of OTU with the species information in the database through python program, and output the predicted result of function (http:// www.zoology.ubc.ca/louca/FAPROTAX/lib/php/index. php?section=Home).

\section{Data Analysis}

A one-way analysis of variance (ANOVA) was conducted to analyze soil chemical conditions and the relative abundance of bacterial functional groups in different soil samples using SPSS 19.0 software (SPSS Inc., USA) with an LSD test [41]. The heat map representation of bacterial functional groups in different samples was established using RStudio packages with the "pheatmap" [42]. The bacterial community functional variation across samples was built via beta diversity analysis, and visualized through nonmetric multidimensional scaling (NMDS) on account of unweighted UniFrac distance metrics [43]. Differences in relative abundance of bacterial ecological functional groups about $\mathrm{C}$ cycle were measured at the $95 \%$




confidence level, and multiple test corrections with Storey's false discovery rate (FDR) was used [44]. The potential relationships between soil environmental factors and the relative abundances of functional groups related to $\mathrm{C}$ and $\mathrm{N}$ cycles were built via Pearson correlation analysis and showed through the heatmap, which was built using RStudio packages with "psych" and "corrplot".

\section{Results and Discussion}

\section{Soil Chemical Characteristics under Different Land Use Patterns}

The vegetation types and soil management of the land surface were determined by different land use types, which in turn affected soil physical and chemical characteristics $[45,21]$. Soil basic chemical properties reflect soil nutrient levels, and the ANOVA for soil properties showed that there were significant differences among different land use patterns. The soil $\mathrm{pH}$ value ranged from 5.54 to 6.29 in samples from all land use types. Soil pH was the highest in SW with 6.29, and the QM and SW had higher $\mathrm{pH}$ value than $\mathrm{LG}$, $\mathrm{PK}$, and ZM. Compared to SW, the ZM land reduced soil $\mathrm{pH}$, which may be mainly due to the increase in $\mathrm{NO}_{3}{ }^{-}-\mathrm{N}$ contents in soil after increasing nitrogen input leads to a decrease in soil $\mathrm{pH}$ [46]. In our study, the $\mathrm{NO}_{3}^{-}-\mathrm{N}$ content in different land use types decreased in the following order $\mathrm{LG}>\mathrm{PK}>\mathrm{ZM}>\mathrm{QM}>\mathrm{SW}$ (Table 1). $\mathrm{NH}_{4}^{+}-\mathrm{N}$ content in $\mathrm{LG}$ and $\mathrm{PK}$ was $6.33 \mathrm{mg} \cdot \mathrm{kg}^{-1}$ and $7.68 \mathrm{mg} \cdot \mathrm{kg}^{-1}$, respectively - significantly higher than the $\mathrm{NH}_{4}^{+}-\mathrm{N}$ contents in QM, SW, and ZM. The natural

Table S1. OTUs per functional group. Number of OTUs assigned to each functional group, compared to the total number of taxonomically annotated OTUs.

\begin{tabular}{|c|c|c|}
\hline Functional group & OTUs & Fraction $(\%)$ \\
\hline Chemoheterotrophy & 1426 & 24.55 \\
\hline Aerobic chemoheterotrophy & 1257 & 21.64 \\
\hline Nitrification & 263 & 4.53 \\
\hline Predatory or exoparasitic & 198 & 3.41 \\
\hline Aerobic ammoniao xidation & 168 & 2.89 \\
\hline Cellulolysis & 143 & 2.46 \\
\hline Nitrate reduction & 142 & 2.44 \\
\hline Respiration of sulfur compounds & 131 & 2.26 \\
\hline Sulfur respiration & 126 & 2.17 \\
\hline Intracellular parasites & 125 & 2.15 \\
\hline Nitrogen fixation & 121 & 2.08 \\
\hline Animal parasites or symbionts & 120 & 2.07 \\
\hline Phototrophy & 115 & 1.98 \\
\hline Fermentation & 98 & 1.69 \\
\hline Ureolysis & 98 & 1.69 \\
\hline Photoautotrophy & 96 & 1.65 \\
\hline Aerobic nitrite oxidation & 95 & 1.64 \\
\hline Nitrogen respiration & 95 & 1.64 \\
\hline Nitrate respiration & 94 & 1.62 \\
\hline Human pathogens all & 83 & 1.43 \\
\hline Photoheterotrophy & 80 & 1.38 \\
\hline Nitrite respiration & 63 & 1.08 \\
\hline Nitrate denitrification & 61 & 1.05 \\
\hline Nitrite denitrification & 61 & 1.05 \\
\hline Nitrous oxide denitrification & 61 & 1.05 \\
\hline Denitrification & 61 & 1.05 \\
\hline
\end{tabular}

\begin{tabular}{|c|c|c|}
\hline Human pathogens pneumonia & 61 & 1.05 \\
\hline $\begin{array}{l}\text { Anoxygenic photoautotrophy S oxidiz- } \\
\text { ing }\end{array}$ & 61 & 1.05 \\
\hline Anoxygenic photoautotrophy & 61 & 1.05 \\
\hline Aromatic compound degradation & 40 & 0.69 \\
\hline Cyanobacteria & 35 & 0.60 \\
\hline Oxygenic photoautotrophy & 35 & 0.60 \\
\hline Chitinolysis & 24 & 0.41 \\
\hline Manganese oxidation & 23 & 0.40 \\
\hline Methylotrophy & 16 & 0.28 \\
\hline Chloroplasts & 13 & 0.22 \\
\hline Hydrocarbon degradation & 10 & 0.17 \\
\hline Methanotrophy & 8 & 0.14 \\
\hline Methanol oxidation & 8 & 0.14 \\
\hline Sulfate respiration & 5 & 0.09 \\
\hline Iron respiration & 5 & 0.09 \\
\hline Human gut & 4 & 0.07 \\
\hline Mammal gut & 4 & 0.07 \\
\hline Dark oxidation of sulfur compounds & 3 & 0.05 \\
\hline Nitrite ammonification & 2 & 0.03 \\
\hline Invertebrate parasites & 2 & 0.03 \\
\hline Thiosulfate respiration & 1 & 0.02 \\
\hline Dark hydrogen oxidation & 1 & 0.02 \\
\hline Nitrate ammonification & 1 & 0.02 \\
\hline Xylanolysis & 1 & 0.02 \\
\hline Dark sulfide oxidation & 1 & 0.02 \\
\hline Aromatic hydrocarbon degradation & 1 & 0.02 \\
\hline
\end{tabular}


secondary forest $(\mathrm{QM})$ had the highest content of total $\mathrm{C}$, total $\mathrm{N}$, and available $\mathrm{N}$ with $57.74 \mathrm{~g} \cdot \mathrm{kg}^{-1}, 4.40 \mathrm{~g} \cdot \mathrm{kg}^{-1}$, and $33.63 \mathrm{mg} \cdot \mathrm{kg}^{-1}$, respectively, followed by LG, while in our study the content of total $\mathrm{C}$, total $\mathrm{N}$, and available $\mathrm{N}$ were lowest in the ZM with $17.46 \mathrm{~g} \cdot \mathrm{kg}^{-1}, 1.31 \mathrm{~g} \cdot \mathrm{kg}^{-1}$, and $11.90 \mathrm{mg} \cdot \mathrm{kg}^{-1}$, respectively. These results support our first hypothesis and are consistent with other research [47]. Numerous studies have also found that soil carbon reserves differ according to different land use patterns [48], and the conversion from forests into farmland reduces soil carbon storage [49-50]. Generally, soils under agricultural land uses showed reduced nutrient concentrations, especially for the contents of total C and total N [51]. Deep tillage after the application of fertilizer in the farmland significantly alter the structure of soil by breaking up soil aggregates, and protecting soil physical structure consequently acceleratesthe release of soil organic carbon into the atmosphere [5253]. Moreover, the litter accumulation in agricultural land was less and the nutrient return was lower. Both of these processes would reduce the input of organic $\mathrm{C}$ into the soil environment and may also explain the reduction of soil total $\mathrm{C}$ and total $\mathrm{N}$, suggesting the loss of soil carbon and nitrogen in the process of transforming forests into other land use patterns. Similarly, previous research hasreported that the concentration of soil organic carbon decreased after conversion of natural forests to Pinus plantations [5, 10, 54], which were similar to our study results.The input of carbon, nitrogen and organic matter in soil is mainly due to the return of nutrients and biological nitrogen fixation in the litter [55]. The biomass allocation strategies between coniferous forests and broad-leaved forests are different. Broad-leaved forests can allocate more biomass to roots, especially fine roots, which in turn fix more carbon into the soil [56]. Meanwhile,the litter of coniferous forests decomposes more slowly compared with broadleaved trees [57], leading to litter accumulation [5859]. Although $L G$ and $P K$ were coniferous forests, the content of soil total $\mathrm{C}$, total $\mathrm{N}$, available $\mathrm{N}$ in LG land were significantly higher than in PK land $(P<0.05)$ (Table 1). A previous study demonstrated that LG belongs to cold-temperate deciduous coniferous forests with a large amount of litter that contains lignin, resin, tannins, and waxy substances that are difficult to decompose. However, the coniferous litter covered on the surface of the soil could promote the formation of an air-free environment and contribute to the accumulation of soil nutrients [60]. On the contrary, PK is a temperate evergreen coniferous forest with less litter, resulting in poor soil nutrients. While no significant differences in soil $\mathrm{C} / \mathrm{N}$ among the samples were observed, and the $\mathrm{C} / \mathrm{N}$ varied from 13.09 to 13.71 . Overall, our results demonstrated that converting secondary forest to pinus plantations and farmland caused a reduction in both the concentration of soil total $\mathrm{C}$ and total $\mathrm{N}$. These findings illustrated that plantations (LG and PK) and farmland (ZM) did not improve soil conditions to the same degree as did QM and SW, and the potentially positive effects of QM on soil nutrient conditions.

\section{Bacterial Functional Annotation and Distribution under Different Land Use Patterns}

FAProTax is more suitable for functional annotation prediction of biogeochemical circulation processes [35]. The relative abundances of bacterial community functional groups in per sample were calculated as the OTUs cumulative abundance allocated to each functional group. OTUs without any functional

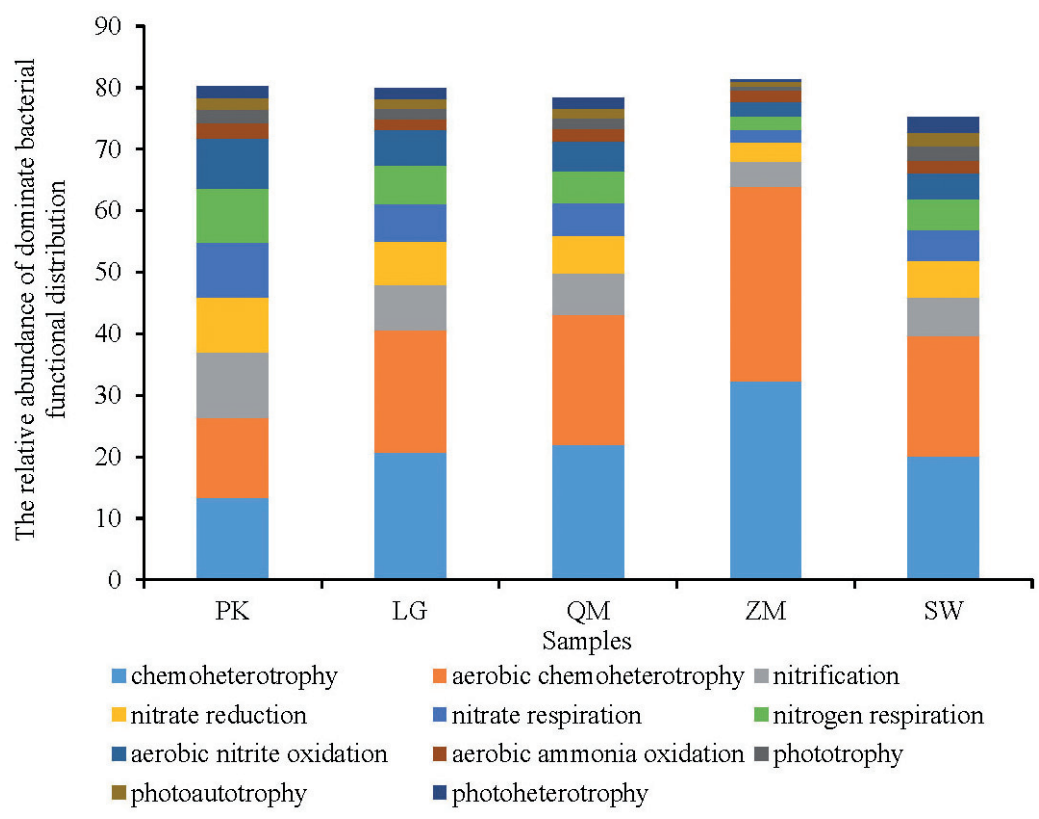

Fig. 1. The relative abundance of dominate bacterial functional groups distribution. QM: Quercus mongolica; SW: Shrub wood; LG: Larix gmelini; PK: Pinus koraiensis; ZM: Zea mays. 
annotation were excluded from the analysis. Then, we inquired about potential functional groups involved in soil environmental conditions. According to the classification annotation results of 16S rDNA sequences, a total of 53 functional groups were obtained using FAProTax. These functional groups contained 5809 OTUs, accounting for $66.25 \%$ of all OTUs. OTUs per functional group are in Table S1.

Functional community function varied across samples in different land use types. The bacterial core functional groups (higher relative abundance $>1.5 \%$ ) are shown in Fig. 1, including chemoheterotrophy, aerobic chemoheterotrophy, nitrification, nitratereduction, nitrogenrespiration, aerobic nitrite oxidation, aerobic ammonia oxidation, phototrophy, photoautotrophy, and photoheterotrophy with average relative abundance of $21.69 \%, 21.01 \%, 7.10 \%, 6.16 \%, 5.49 \%, 5.49 \%, 5.10 \%$, $2.00 \%, 1.74 \%, 1.62 \%$, and $1.60 \%$, respectively (Fig. 1). In our study, the predominant functional groups were chemoheterotrophy and aerobic chemoheterotrophy.
Abundant chemoheterotrophy in soil indicated that a large number of microbes cannot fix carbon and have to obtaincarbon and energy from the oxidation of preformed organic compounds [61]. The bacterial community functional groups from soil differed from those of mudflat, and previous study from the mangroveinhabited mudflat revealed that photoautotrophy and nitrate respiration were a rich repertoire of metabolic functional groups [61]. Bacterial functional distribution under different land use patterns changed significantly. A hierarchically clustered heatmap was eatablished based on all the bacterial functional groups, and the differences of relative abundances of soil bacterial functional groups among samples from different land use types were reflected by the heatmap. The results showed that the five soil samples were divided into two large groups. One group contained the QM, SW, LG, and PK, and the other group was ZM (Fig. 2). The NMDS plot also indicated that the bacterial functional groups of ZM were separated from those of PK, LG,

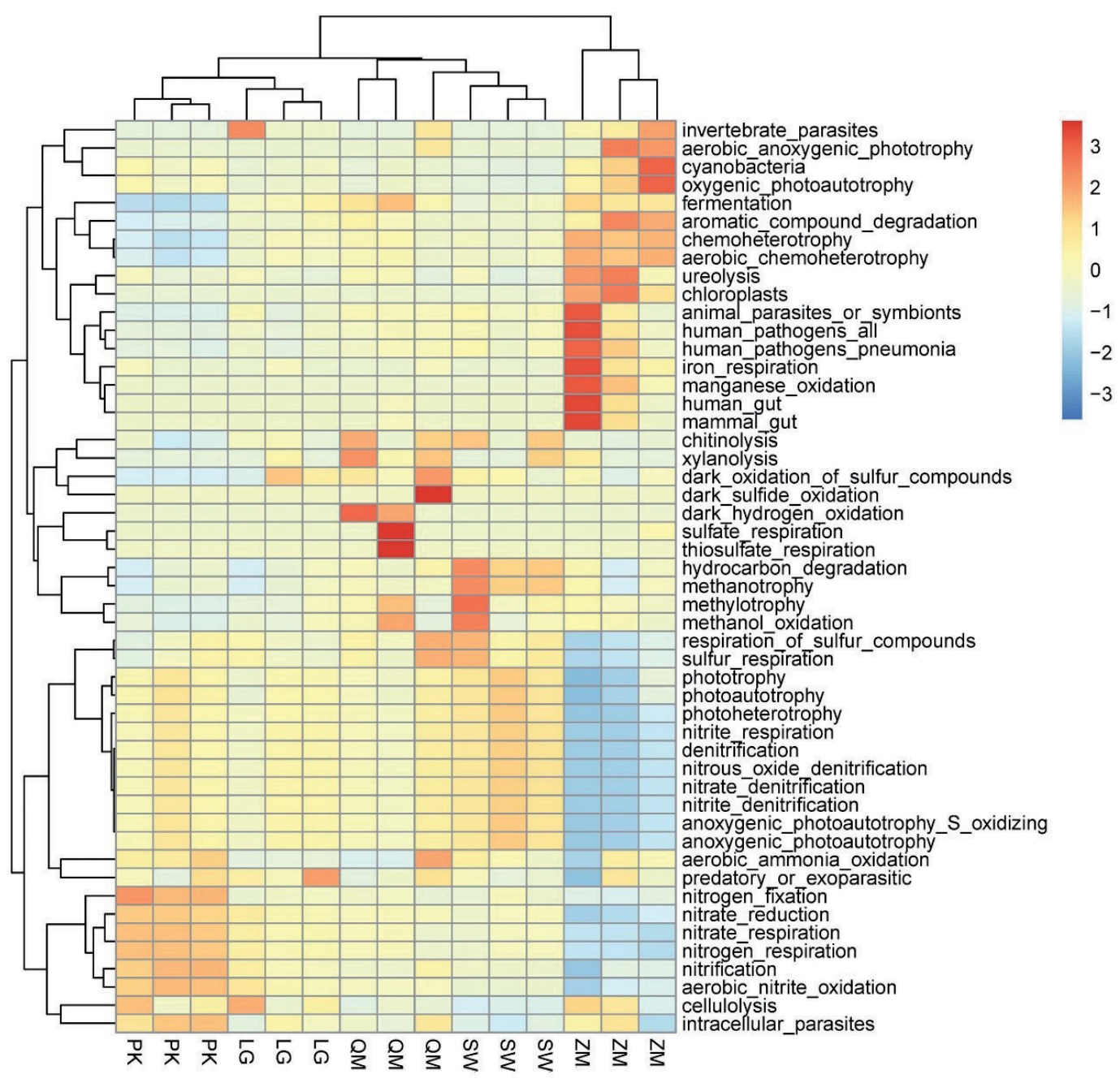

Fig. 2. Distribution of bacterial function in the FaProTax database for different land use patterns. Different colors indicate the relative abundance of groups in the individual samples. The samples are grouped according to the similarity of each other, and the clustering results are arranged horizontally according to the clustering results. In the figure, red represents the function with higher abundance in the corresponding sample, and blue represents the function with lower abundance. QM: Quercus mongolica; SW: Shrub wood; LG: Larix gmelini; PK: Pinus koraiensis; ZM: Zea mays. 


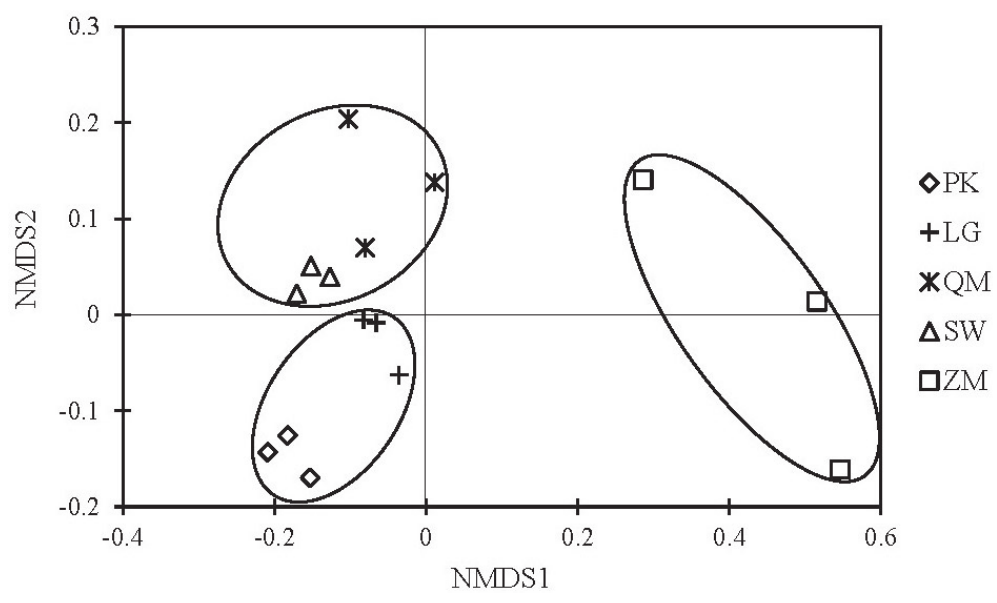

Fig. 3. Results of nonmetric multidimensional scaling analysis-Biplot of the all investigated bacterial functional distribution. QM: Quercus mongolica; SW: Shrub wood; LG: Larix gmelini; PK: Pinus koraiensis; ZM: Zea mays.

QM, and SW, especially along NMDS1, indicating that bacterial functional groups of agriculture soil differed from those of forests. This indicated that the conversion of forest land to cultivated land and the application of long-term chemical fertilizers have changed the main metabolic groups of soil microorganisms. Compared with forest land, cultivated land has obvious changes in its surface vegetation, which has led to changes in root exudates. Studies have shown that root exudates play an important role in the distribution of soil microbes, directly affecting the quantity, activity and community structure of soil microbes [62], and its soil physical and chemical properties have also changed significantly. The combined effects of these differences have led to significant changes in the bacterial community functional groups of farmland. In addition, the bacterial functional groups of LG, and PK were separated from those of QM and SW, especially along NMDS2 (Fig. 3), indicating that functional groups of broadleaf forest differed from those of coniferous forests. Both of them illustrated that similar land-use patterns usually have similar soil bacterial community functional groups in a specific area. Also, a finding from the semiarid Loess Plateau region in China established that similar land-use types in a specific area generally have similar soil chemical properties, and similar microbial communities [63], which supported our research results to some extent. Previous study documented that planted forests change bacterial community composition compared to natural broad leaf forests, and soil bacterial physiological characteristics indicated the potential ecological role for nutrient cycles in the ecosystem [64], which proved our research conclusions to some degree. Under the same climatic conditions, the differences between broad-leaved forests and coniferous forests serve as an important factor affecting bacterial community functional groups. Thus it can be seen that different land use patterns could distinctly influence the decomposer community composition owing to the different vegetation types [65].
Due to the existence of functional gene redundancy, these functional profiles were observed among bacterial communities [66].

\section{Functional Groups Related to the C and N Cycles under Different Land Use Patterns}

The $\mathrm{C}$ and $\mathrm{N}$ cycles of the terrestrial ecosystem and its regulation mechanism are the hot topics in the science research of soil ecology and global change ecology [67]. As is known to all, soil bacterial communities provide an important role in biogeochemical cycles [68]. Under the background of global climate change, the diversity of soil microorganism is bound to be affected, and the change of biological diversity affects the change of soil carbon and nitrogen. Land use and land cover change impact plant litter on the soil surface, and environmental conditions, such as water and heat, the transformation and flow of soil nutrients, and the quantity, composition, and activity of soil microorganisms [69]. The decomposition of specific carbon substrates of different land use patterns could determine the different community composition and functional group of soil bacteria [70-71]. In our study, we detected 15 ecological function groups related to the $\mathrm{C}$ cycles, including chemoheterotrophy, aerobic chemoheterotrophy, phototrophy, photoautotrophy, photoheterotrophy, anoxygenic photoautotrophy $\mathrm{S}$ oxidizing, anoxygenic photoautotrophy, cellulolysis, aromatic compound degradation, oxygenic photoautotrophy, methylotrophy, methanol oxidation, hydrocarbon degradation, methanotrophy, and aromatic hydrocarbon degradation (Table S2). However, previous studies from a temperate deciduous broad leaved forest and a tropical mountain rainforest detected eight ecological function groups connected with the carbon cycles [71]. In our research, after the conversion from SW to ZM, soil bacterial function for aerobic chemoheterotrophy $(P=0.0005)$ and chemoheterotrophy $(P=0.0016)$ significantly increased (Fig. 4), while, 


\begin{tabular}{|c|c|c|c|c|c|c|c|c|c|c|c|}
\hline &  & 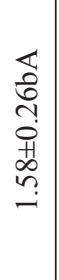 & 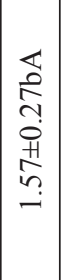 & 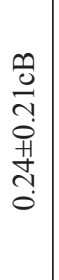 & 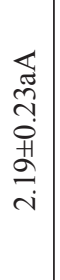 & 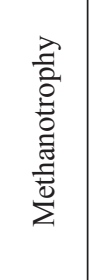 & $\mid \begin{array}{c}m \\
0 \\
0 \\
0 \\
0 \\
+1 \\
0 \\
0 \\
0\end{array}$ & $\begin{array}{l}\frac{m}{0} \\
0 \\
0 \\
0 \\
+ \\
0 \\
\dot{0}\end{array}$ & 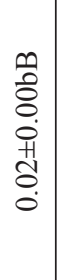 & $\begin{array}{c}m \\
0 \\
0 \\
0 \\
\dot{1} \\
\stackrel{1}{0} \\
\dot{0}\end{array}$ & 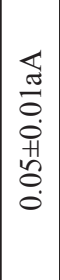 \\
\hline & 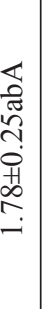 & 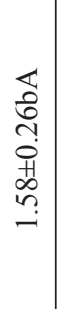 & 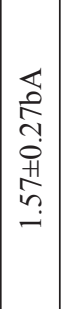 & 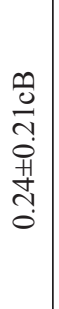 & 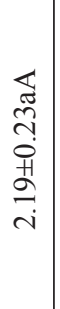 & 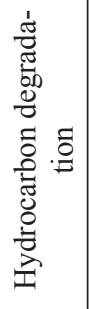 & $\begin{array}{c}m \\
0 \\
0 \\
0 \\
\dot{0} \\
\dot{0} \\
0 \\
0\end{array}$ & $\begin{array}{c}\frac{m}{0} \\
0 \\
0 \\
\dot{+} \\
0 \\
0 \\
0\end{array}$ & $\begin{array}{c}m \\
0 \\
0 \\
0 \\
\dot{1} \\
\stackrel{1}{0} \\
\dot{0}\end{array}$ & $\begin{array}{c}0 \\
0 \\
0 \\
0 \\
\dot{+} \\
\stackrel{1}{0} \\
0 \\
0\end{array}$ & 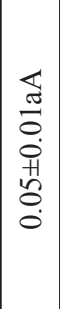 \\
\hline & 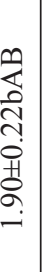 & 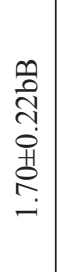 & 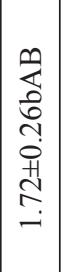 &  &  & 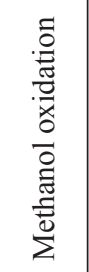 &  & 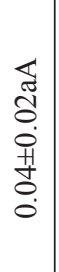 & $\begin{array}{l}\mathbb{a} \\
0 \\
0 \\
0 \\
\dot{1} \\
0 \\
0 \\
0\end{array}$ & 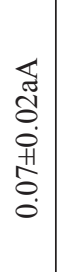 & $\mid \begin{array}{c}\mathbb{J} \\
0 \\
0 \\
0 \\
0 \\
0 \\
0 \\
0 \\
0\end{array}$ \\
\hline & 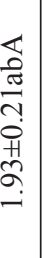 & 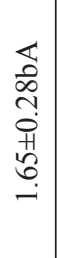 & 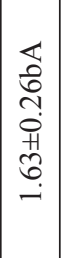 & 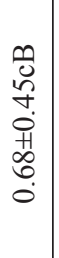 & 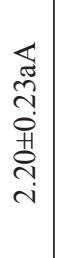 & 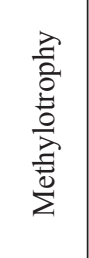 & 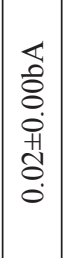 & $\begin{array}{l}\overleftrightarrow{1} \\
\tilde{\pi} \\
\delta \\
0 \\
0 \\
0 \\
0 \\
0\end{array}$ & 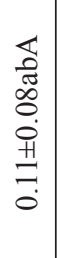 &  &  \\
\hline & 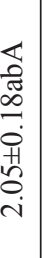 & 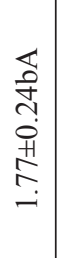 & 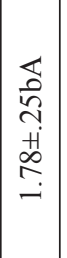 &  &  & 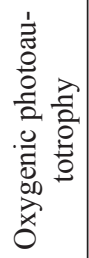 & $\begin{array}{l}m \\
0 \\
n \\
0 \\
0 \\
0 \\
0 \\
0 \\
0 \\
0\end{array}$ & 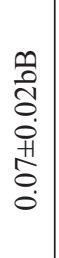 & 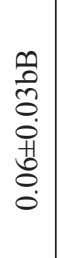 & 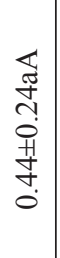 & \begin{tabular}{|c|c}
$\frac{m}{0}$ \\
$\vdots$ \\
0 \\
0 \\
0 \\
+1 \\
$\vdots$ \\
0 \\
0
\end{tabular} \\
\hline & 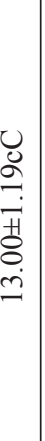 & 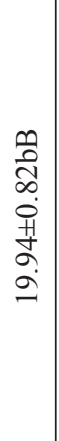 & 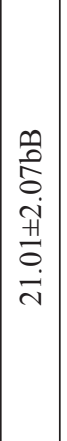 & 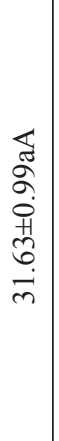 & 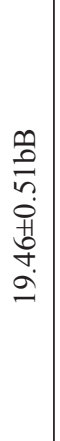 &  & 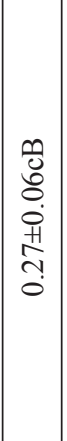 & $\begin{array}{l}m \\
0 \\
0 \\
0 \\
0 \\
0 \\
0 \\
0 \\
0 \\
0\end{array}$ & $\begin{array}{l}\frac{m}{2} \\
\stackrel{0}{0} \\
\stackrel{0}{0} \\
\dot{0} \\
\infty \\
0\end{array}$ &  & 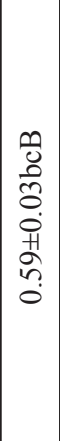 \\
\hline & 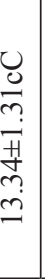 & 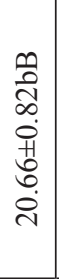 & 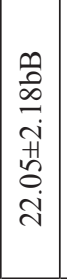 & 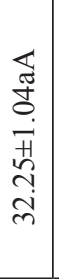 & 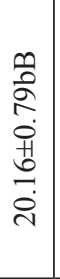 & $\begin{array}{l}\frac{n}{0} \\
\frac{2}{2} \\
\frac{0}{3} \\
\frac{0}{0}\end{array}$ & $\mid \begin{array}{c}\mathbb{d} \\
\tilde{n} \\
\tilde{0} \\
0 \\
0 \\
\infty \\
0 \\
0\end{array}$ & 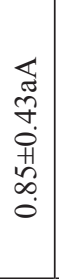 & $\begin{array}{l}\mathbb{1} \\
\stackrel{\infty}{\infty} \\
0 \\
0 \\
0 \\
+1 \\
\infty \\
0 \\
0\end{array}$ & 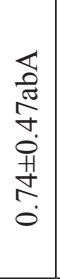 &  \\
\hline & $\frac{4}{2}$ & $\stackrel{9}{0}$ &  & $\sum_{N}$ & $\vec{u}$ & 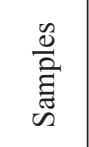 & $\frac{v}{2}$ & త్త & $\sum$ & $\sum_{N}$ & 齐 \\
\hline
\end{tabular}

soil bacterial function for photoheterotrophy $(P=0.0004)$, photoautotrophy $(P=0.0023)$, phototrophy $(P=0.0044)$, anoxygenic photoautotrophy $\mathrm{S}$ oxidizing $(P=0.0006)$, and anoxygenic photoautotrophy $(P=0.0006)$ significantly decreased (Fig. 4). The functional groups of the bacterial community related to $\mathrm{C}$ cycling in long-term agricultural soil is significantly altered from the original forest ecosystem, which was consistent with a previous study [62]. This may be due to the fact that fertilization in farmland can directly provide a large amount of carbon sources for microorganisms and promote the assimilation, utilization of carbon by microorganisms, thereby promoting the increase of chemical heterotrophic microbes. Different vegetation types could cause changes in bacterial community function in the soil. In our study, comparedwith coniferous forests, the soil bacterial functional abundance of aerobic chemoheterotrophy and chemoheterotrophy in QM were the highest with $22.05 \%$, and $21.01 \%$, respectively (Table S2). However, we found no significant differences with LG. Compared to the LG, soil bacterial function for aerobic chemoheterotrophy $(P=0.0223)$ and chemoheterotrophy $(P=0.0303)$ in PK significantly decreased, while phototrophy $(P=0.0242)$ and photoautotrophy $(P=0.0306)$ significantly increased (Fig. 5). Accordingly, the soil bacterial community function groups were closely related to the species of aboveground plants, which could provide various nutrients through the litters and root exudates, altering the growth environment of soil bacteria and eventually leading to the changes in the soil bacterial community functional groups [72].

Soil nitrogen fixation, nitrification, denitrification, ammonification, and other major nitrogen transformation processes are mainly mediated by soil bacteria [73]. And the soil $\mathrm{N}$ cycles,especially biological nitrification and denitrification processes, can affect the production and emission of such greenhouse gases as $\mathrm{CO}_{2}, \mathrm{CH}_{4}$, and $\mathrm{N}_{2} \mathrm{O}$ [74]. And the problem of land degradation and ecological function change caused by the change of land use mode has been widely concerned [75-77]. Therefore, it is particularly important to clarify the microbiological mechanism of the nitrogen transformation process in response to different land use types. In our study, we examined 12 ecological function groups connected to the $\mathrm{N}$ cycles, including nitrification, aerobic ammonia oxidation, nitrate reduction, nitrogen fixation, aerobic nitrite oxidation, nitrogen respiration, nitrate respiration, nitrite respiration, nitrate denitrification, nitrite denitrification, nitrous oxide denitrification, and denitrification (Table S3), which was similar to [71]. Bacterial community function for nitrification, nitrate reduction, nitrate respiration, nitrogen respiration, aerobic nitrite oxidation,aerobic ammonia oxidation, nitrate denitrification, nitrite denitrification, nitrous oxide denitrification, denitrification, nitrite respiration, and nitrogen fixation in $\mathrm{ZM}$ were $4.18 \%, 3.01 \%, 2.14 \%$, $2.14 \%, 2.38 \%, 1.80 \%, 0.27 \%, 0.27 \%, 0.27 \%, 0.27 \%$, $0.27 \%$, and $0.11 \%$, respectively - significantly decreased 

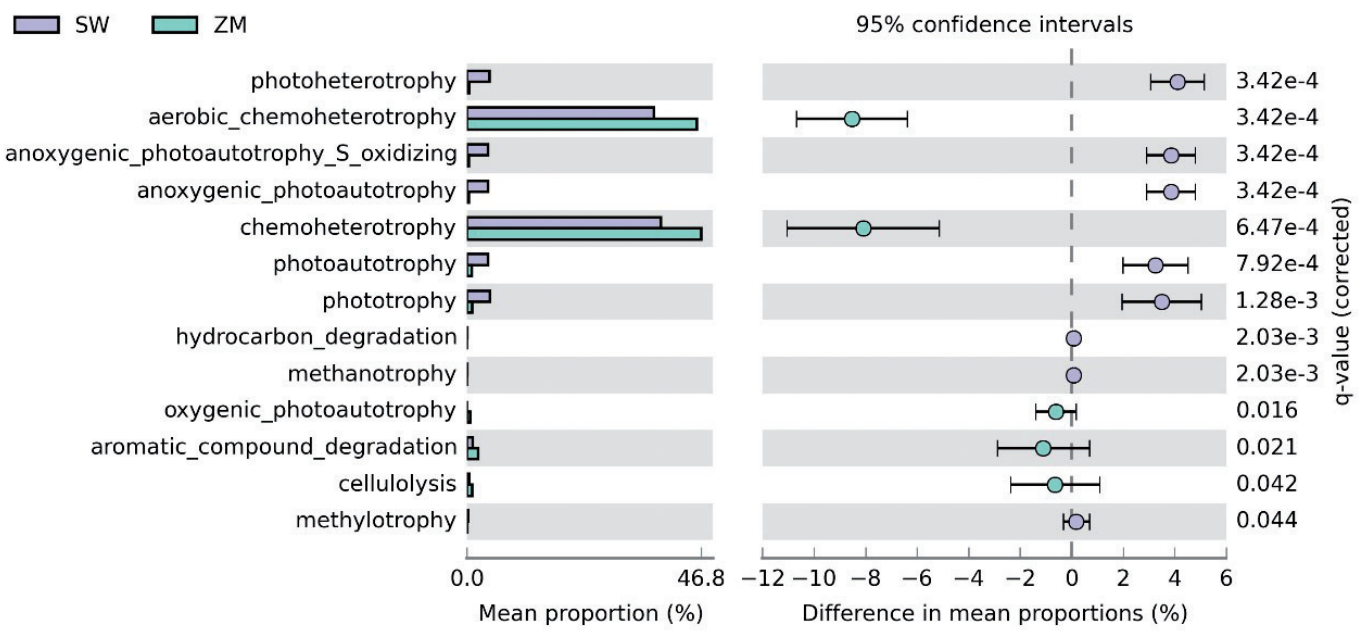

Fig. 4. Differences in relative abundance of function between SW and ZM sites. Only significantly different function are shown, with corrected P-values calculated using Storey's FDR approach (Two-sided) $(\mathrm{P}<0.05)$. Error bars show 95\% confidence intervals. ZM, Zea mays; SW, Shrub wood.

compared to forest soils (Table S3). And nitrate denitrification, nitrite denitrification, and denitrification related to the nitrogen cycle showed a significant difference between ZM and forest soil $(P<0.01)$ (Table S3), and significantly higher in the forests. The reason for this difference might be due to the existence of the denitrifying genes (nirS, nirK, and nosZ) in soil microorganisms. Previous research from Lammel et al. [78] reported that the variation pattern of functional gene abundance of microorganisms related to $\mathrm{N}$ cycling during the transition from forest to farmland, and the results showed that the abundance of functional genes in forest soil were significantly higher than that in farmland, which confirmed our results to some extent. Conversion of forests to agricultural land uses reduces litter inputs [79], and forest vegetation showed more refractory substances, and carbon and nitrogen contents [80]. With the increase of litter and plant root exudates in forest ecosystems, soil nitrogen content increased, which stimulated the growth and reproduction of denitrifying microorganisms, significantly increased microbial activity, and altered $\mathrm{N}$ cycles.

To our knowledge, this is the first attempt to clarify the differences of bacterial community functional groups between forest soils (QM, SW, LG, and PK) and agricultural soil (ZM) in the mountainous region of eastern Liaoning Province, China. These conclusions might be explained by the soils at the forest and agriculture sites maybe having different functional groups for the $\mathrm{C}$ and $\mathrm{N}$ cycles. And LG and PK lands had similar bacterial function compared to the QM land. However, FAPROTAX is not a substitute for a whole metagenome profiling, which may pose a problem when the analysis of the microbiome contains large amounts of uncultured bacteria and does not involve the function of the ancient community. $\square$ PK $\square$ LG

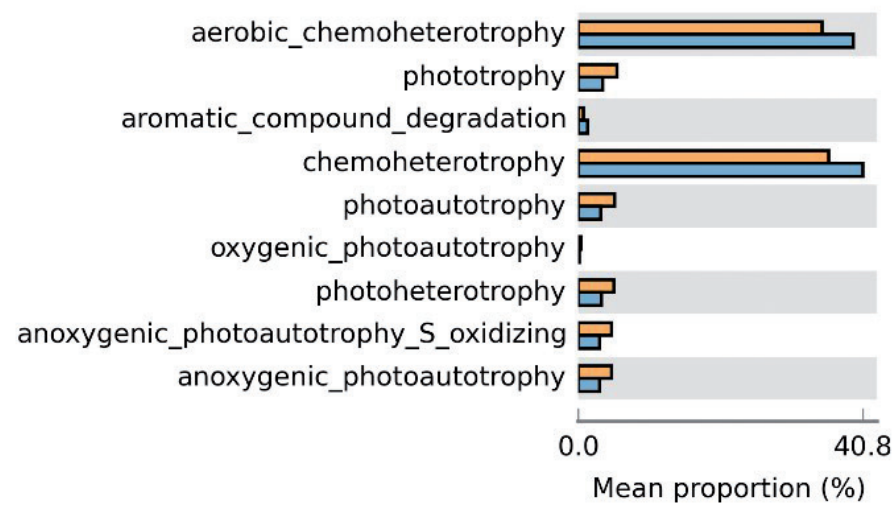

$95 \%$ confidence intervals

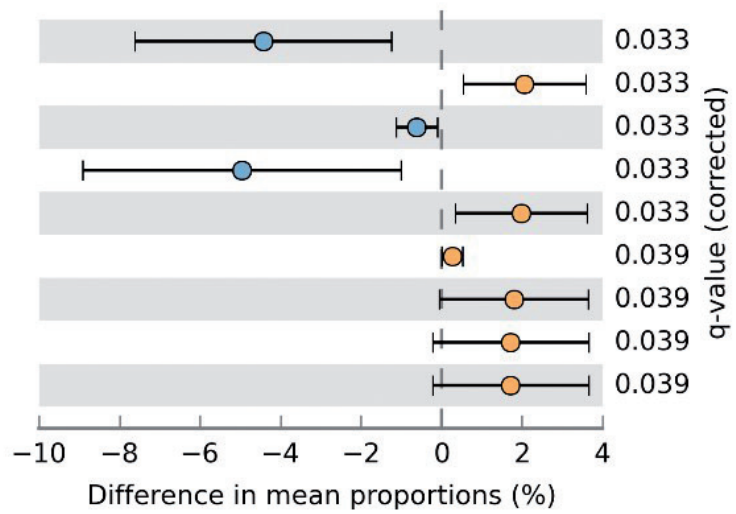

Fig. 5. Differences in relative abundance of function between PK and LG. Only significantly different function are shown, with corrected $\mathrm{P}$-values calculated using Storey’s FDR approach (Two-sided) $(\mathrm{P}<0.05)$. Error bars show $95 \%$ confidence intervals. LG: Larix gmelini; PK, Pinus koraiensis. 


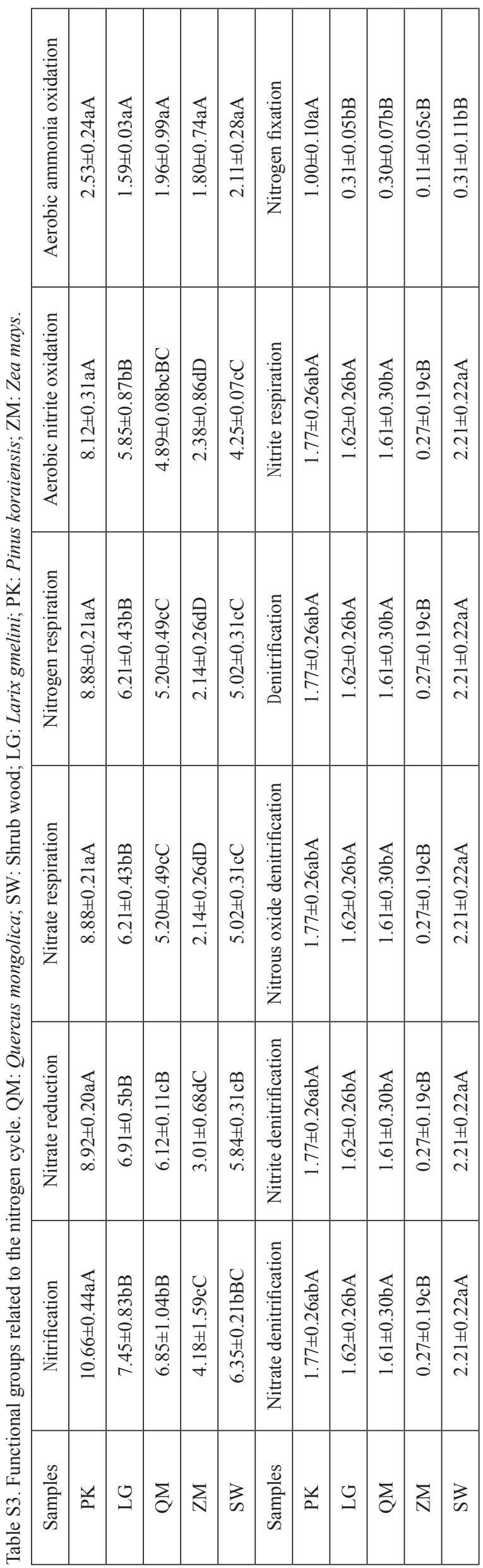

Relationships between Bacterial Community Functional Groups and Soil Environmental Factors

Canonical correspondence analysis (CCA) was applied to explore the soil environmental factors and functional groups related to the $\mathrm{C}$ and $\mathrm{N}$ cycles. The first and second axes accounted for $94.2 \%$ and $93.7 \%$ of the variation, respectively, indicating that soil environmental factors significantly influence the bacterial community functional groups (Fig. 6). In terms of $\mathrm{C}$ cycles, soil $\mathrm{pH}(\mathrm{r}=0.7451), \mathrm{NH}_{4}^{+}-\mathrm{N}(\mathrm{r}=-0.5606)$, and $\mathrm{NO}_{3}{ }^{-}-\mathrm{N}$ $(\mathrm{r}=-0.6784)$ were significantly correlated with axis1, and the first axial interpretation rate was $88.0 \%$ (Fig. 6a). In terms of $\mathrm{N}$ cycles, soil $\mathrm{pH}(\mathrm{r}=0.6093)$, and $\mathrm{NH}_{4}^{+}-\mathrm{N}$ $(\mathrm{r}=-0.6293)$ were significantly correlated with axis2, and the second axial interpretation rate was $40.7 \%$ (Fig. 6b).

To further explore the relative importance of individual environmental variables, we performed the Pearson correlation analysis of the relative abundances of functional groups within each functional group, using eight key environmental variables as shown in Fig. 7. Soil $\mathrm{pH}$ was significantly negatively correlated with phototrophy $(\mathrm{r}=-0.57, P<0.05)$, photoautotrophy $(\mathrm{r}=-0.61, P<0.05)$, photoheterotrophy $(\mathrm{r}=-0.61$, $P<0.05$ ), anoxygenic photoautotrophy $\mathrm{S}$ oxidizing $(\mathrm{r}=-0.65, P<0.05)$, and anoxygenic photoautotrophy $(\mathrm{r}=-0.65, P<0.05)$ (Fig. 7a). Our results were consistent with a previous study that indicated that (oxygenic) photoautotrophy was negatively correlated to soil $\mathrm{pH}$ value [61]. In our study, the content of $\mathrm{NO}_{3}^{-}-\mathrm{N}$ was negatively correlated to chemoheterotrophy $(\mathrm{r}=-0.72$, $P<0.01)$, aerobic chemoheterotrophy $(\mathrm{r}=-0.71, P<0.01)$, and aromatic compound degradation $(\mathrm{r}=-0.64, P<0.01)$, which haspositive correlation with photoheterotrophy $(\mathrm{r}=0.55, \quad P<0.05)$, anoxygenic photoautotrophy $\mathrm{S}$ oxidizing $(\mathrm{r}=0.55, \quad P<0.05)$, and anoxygenic photoautotrophy $(\mathrm{r}=0.55, P<0.05)$. Also, a past study documented that the content of $\mathrm{NO}_{3}^{-}-\mathrm{N}$ was the dominating environmental factor related to $\mathrm{C}$ cycle [71]. The decomposition potential of soil microbes to refractory carbon is greatly affected by soil $\mathrm{N}$ content.

The processes of soil microorganism nitrification and denitrification are affected by various physical, and chemical factors, such as soil moisture condition, $\mathrm{NH}_{4}^{+}-\mathrm{N}$ and $\mathrm{NO}_{3}^{-}-\mathrm{N}$ contents, soil organic matter, and so on [81]. We found that soil environmental conditions (especially soil $\mathrm{pH}, \mathrm{NH}_{4}^{+}-\mathrm{N}$, and $\mathrm{NO}_{3}^{-}-\mathrm{N}$ contents) strongly influenced the distribution of functional groups about $\mathrm{C}$ and $\mathrm{N}$ cycles in bacterial communities. In our study, soil $\mathrm{pH}$ was significantly negatively correlated with nitrification $(\mathrm{r}=-0.68, P<0.01)$, nitrate reduction $(\mathrm{r}=-0.78, P<0.01)$, nitrate respiration $(\mathrm{r}=-0.81, P<0.01)$, nitrogen respiration $(\mathrm{r}=-0.81, P<0.01)$, aerobic nitrite oxidation $(\mathrm{r}=-0.74, P<0.01)$, nitrate denitrification $(\mathrm{r}=-0.64, P<0.01)$, nitrite denitrification $(\mathrm{r}=-0.64$, $P<0.01)$, nitrous oxide denitrification $(\mathrm{r}=-0.64, P<0.01)$, denitrification $(\mathrm{r}=-0.64, P<0.01)$, nitrite respiration $(\mathrm{r}=-0.64, P<0.01)$, and nitrogen fixation $(\mathrm{r}=-0.61$, 
$P<0.05)$. A previous study suggested that nitrification is negatively correlated to soil $\mathrm{pH}$ [61], which was similar to our study results. Soil $\mathrm{pH}$ not only affects the process of soil nitrification via the activity and composition of nitrifying microorganisms, but it also can directly affect the activity of denitrifying microorganisms and the denitrification process [82]. The reason may be that $\mathrm{pH}$ changes the chemical form, concentration and effectiveness of substrates in forest soil, thus affecting the nitrifying and denitrifying bacterial community and metabolic activity. Enwall et al. used nosZ and narG genes as functional markers of denitrifying

a)

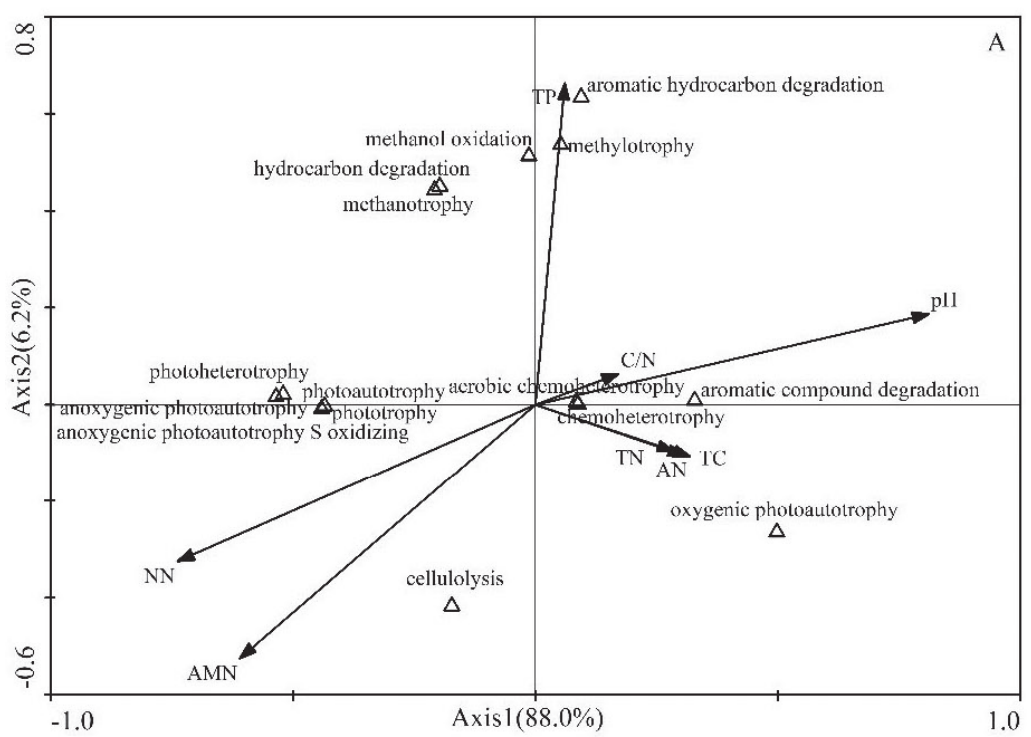

b)

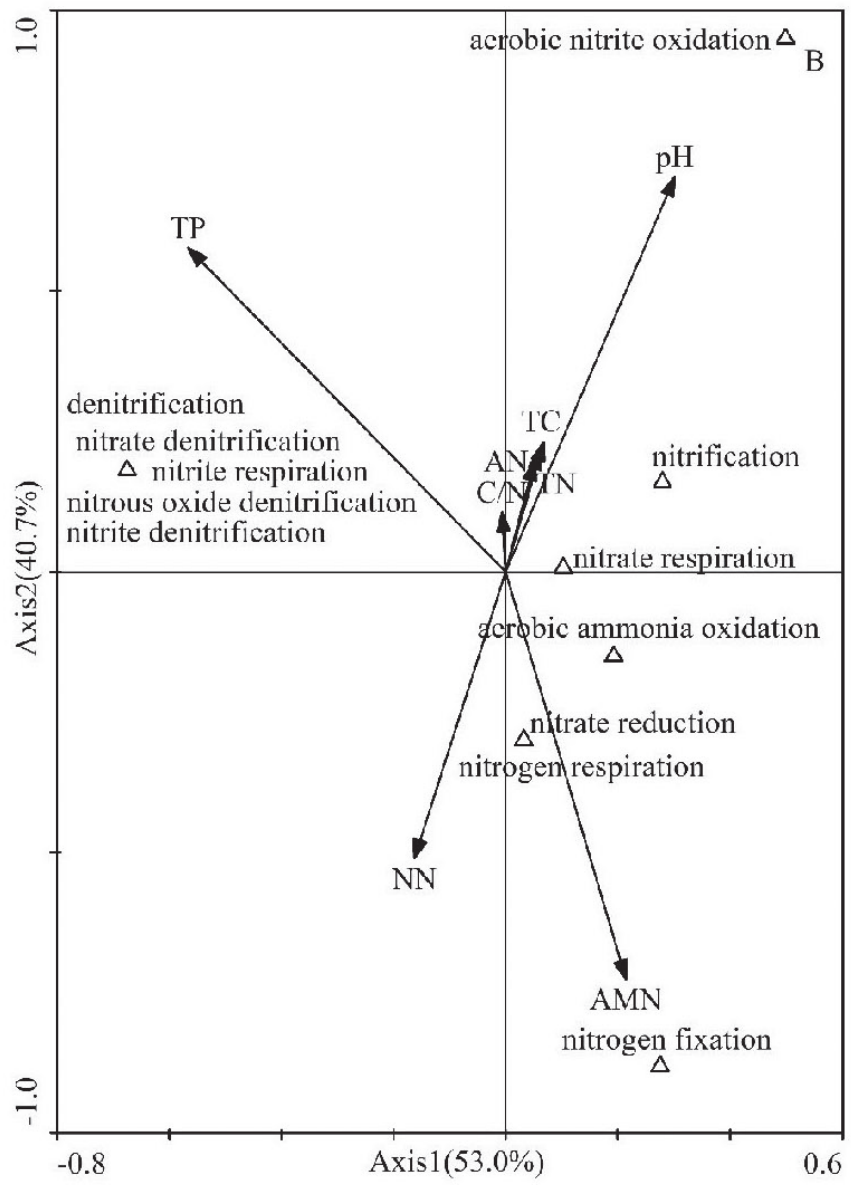

Fig. 6. Canonical correlation analysis (CCA) of the predicted FAPROTAX functions associated with soil physiochemical properties. a) Functional groups that are related to carbon cycle. b) Functional groups that are related to nitrogen cycle. QM: Quercus mongolica; SW: Shrub wood; LG: Larix gmelini; PK: Pinus koraiensis; ZM: Zea mays. 
a)

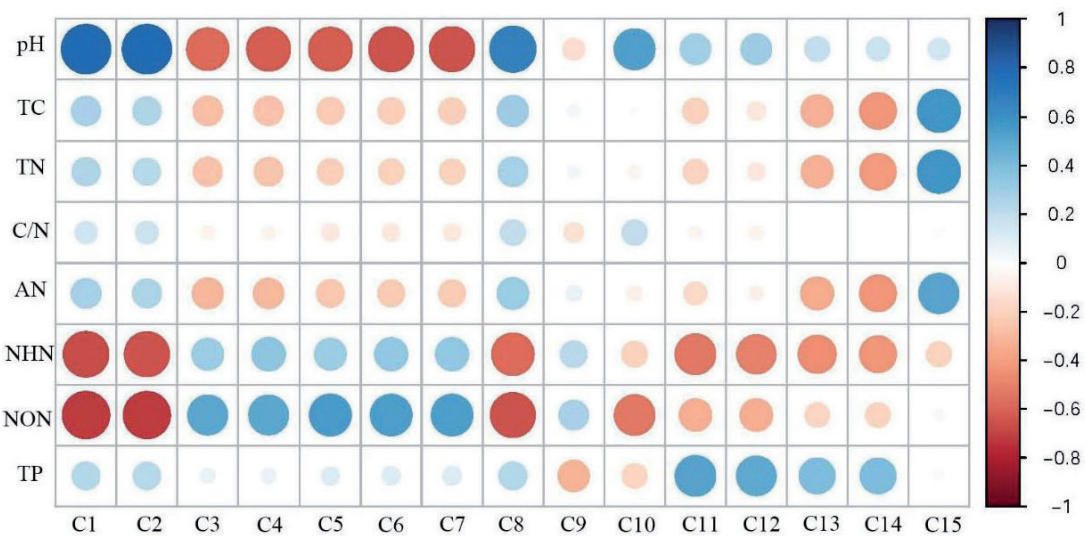

b)

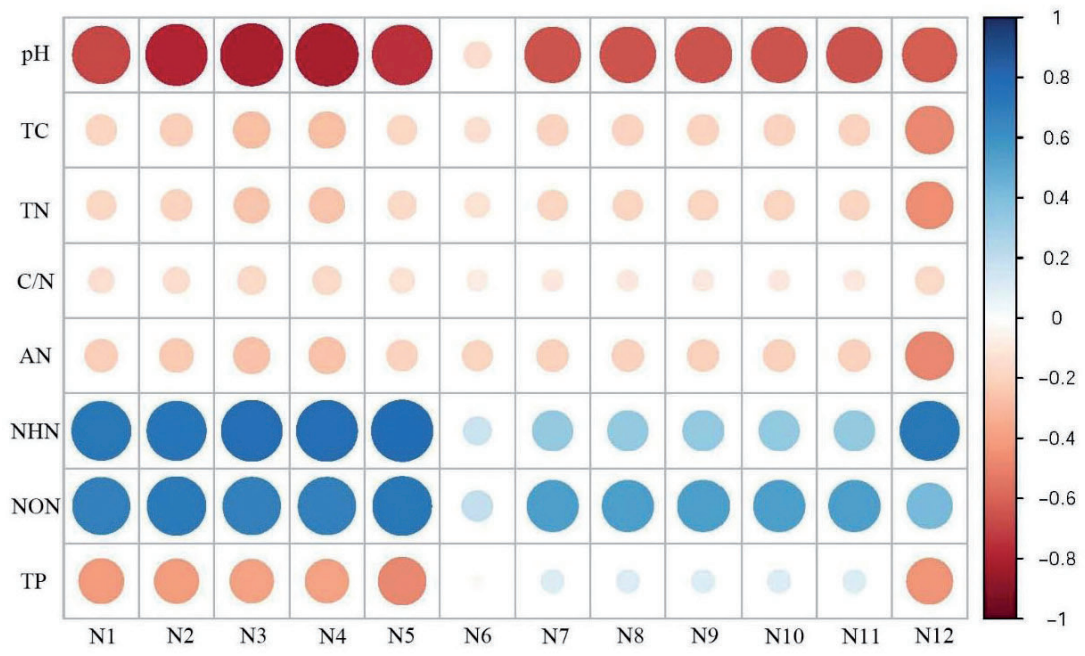

Fig. 7. Rank correlations between soil environmental variables and functional groups that are related to carbon cycle (A) and nitrogen cycle (B). Blue and red colors indicate positive and negative correlations, respectively. Functional groups related to the carbon cycle and nitrogen carcle in the Table S2.

bacteria to explore the effect of applying organic and inorganic fertilizers on the activity and composition of denitrifying bacteria in cultivated soil. It was found that the long-term application of $\left(\mathrm{NH}_{4}\right)_{2} \mathrm{SO}_{4}$ resulted in the changes of soil $\mathrm{pH}$, resulting in changes in the composition of the denitrifying bacteria community [82]. $\mathrm{NH}_{4}^{+}-\mathrm{N}$ was significantly positively correlated with nitrification $(\mathrm{r}=0.73, P<0.01)$, nitrate reduction $(\mathrm{r}=0.73, P<0.01)$, nitrate respiration $(\mathrm{r}=0.78, P<0.01)$, nitrogen respiration $(\mathrm{r}=0.78, P<0.01)$, aerobic nitrite oxidation $(\mathrm{r}=0.79, P<0.01)$, and nitrogen fixation $(\mathrm{r}=0.73$, $P<0.01)$. $\mathrm{NO}_{3}^{-}-\mathrm{N}$ was significantly positively correlated with nitrification $(\mathrm{r}=0.68, P<0.01)$, nitrate reduction $(\mathrm{r}=0.72, P<0.01)$,nitrate respiration $(\mathrm{r}=0.69, P<0.01)$, nitrogen respiration $(\mathrm{r}=0.69, P<0.01)$, aerobic nitrite oxidation $(\mathrm{r}=0.73, \quad P<0.01)$, nitrate denitrification $(\mathrm{r}=0.55, P<0.05)$, nitrite denitrification $(\mathrm{r}=0.55$, $P<0.05)$, nitrous oxide denitrification $(\mathrm{r}=0.55, P<0.05)$, denitrification $(\mathrm{r}=0.55, P<0.05)$, and nitrite respiration $(\mathrm{r}=0.55, P<0.05)$ (Fig. 7b). In our study, the contents of $\mathrm{NH}_{4}^{+} \mathrm{-}$ N showed significantly positive correlation with aerobic nitrite oxidation. As the first substrate of nitrification, a stable supply of $\mathrm{NH}_{4}^{+}{ }^{+} \mathrm{N}$ is necessary to maintain the population activity of ammonia oxides, and the availability of $\mathrm{NH}_{4}^{+}-\mathrm{N}$ plays an important role in regulating the process of ammonia oxidation [84]. In addition, research by Petersen et al. found that the AOA community structure was significantly correlated with the content of $\mathrm{NH}_{4}^{+}-\mathrm{N}$ [85]. A previous study indicated that nitrification rate was significantly positively correlated with soil $\mathrm{NH}_{4}^{+}-\mathrm{N}$ content, and denitrification rate was significantly positive correlation with soil $\mathrm{NO}_{3}^{-}-\mathrm{N}$ content. However, some studies have reported that the higher the soil organic matter content, the greater the denitrification potential [86]. In consequence, the change in the soil bacterial community functional groups caused by land-use change is linked to changes in soil environment factors - especially soil $\mathrm{pH}, \mathrm{NH}_{4}^{+}-\mathrm{N}$, and $\mathrm{NO}_{3}^{-}-\mathrm{N}$ contents.

\section{Conclusions}

In conclusion, bacterial functional groups varied across samples under different land use patterns. The dominant functions were chemoheterotrophs 
and aerobic chemoheterotrophy with average relative abundance of $21.69 \%$ and $21.01 \%$, respectively. In addition, we detected 15 and 12 ecological function groups related to the carbon cycles, and nitrogen cycles, respectively. It seems that similar land-use patterns usually have similar soil bacterial community functional groups in a specific area. The bacterial functional groups of ZM were clearly separated from those of PK, LG, QM, and SW, indicating that functional groups of agriculture soil differed from those of forest soils. Furthermore, the bacterial functional groups of LG and PK were obviously separated from those of QM and SW, suggesting that functional groups of broadleaf forest differed from those of coniferous forests. Soil environmental conditions, especially soil $\mathrm{pH}, \mathrm{NH}_{4}^{+}-\mathrm{N}$, and $\mathrm{NO}_{3}^{-}-\mathrm{N}$ content, strongly influenced the distribution of functional groups about carbon and nitrogen cycles in bacterial communities.

\section{Acknowledgements}

This research was financially supported by the Startup Foundation for Doctors of Liaoning (20170520064) and the Special Fund for Forest Scientific Research in the Public Welfare (201304216).

\section{Conflict of Interest}

The authors declare no conflict of interest

\section{References}

1. PABST H., KUHNEL A., KUZYAKOV Y. Effect of land-use and elevation on microbial biomass and water extractable carbon in soils of Mt. Kilimanjaro ecosystems. Appl Soil Ecol. 67, 10, 2013.

2. MEYER K.M., KLEIN A.M., RODRIGUES J.L., NUSSLEIN K., TRINGE S.G., MIRZA B.S., TIEDJE J.M., BOHANNAN B.J. Conversion of Amazon rainforest to agriculture alters community traits of methane-cycling organisms. Mol Ecol. 26 (6), 1547, 2017

3. LI Y., ZHANG J., CHANG S.X., JIANG P.K., ZHOU G., SHEN Z., WU J., LIN L., WANG Z., SHEN M. Converting native shrub forests to Chinese chestnut plantations and subsequent intensive management affected soil $\mathrm{C}$ and $\mathrm{N}$ pools. Forest Ecol Manag. 312, 161, 2014.

4. TADESSE G., ZAVALETA E., SHENNAN C. Effects of land-use changes on woody species distribution and above-ground carbon storage of forest-coffee systems. Agr Ecosyst Enviro. 197, 21, 2014.

5. FANG X., ZHANG J., MENG M., GUO X., WU Y., LIU X., ZHAO K., DING L.Z., SHAO Y.F., WEI J. Forest-type shift and subsequent intensive management affected soil organic carbon and microbial community in southeastern China. Eur J Forest Res. 136 (1), 689, 2017.

6. HOLLAND T.C., BOWEN P.A., BOGDANOFF C.P., LOWERY D.T., SHAPOSHNIKOVA O., SMITH S., HART M. Evaluating the diversity of soil microbial communities in vineyards relative to adjacent native ecosystems. Appl Soil Ecol. 100, 91, 2016.

7. WU X., LI Z, FU B, ZHOU W., LIU H., LIU G. Restoration of ecosystem carbon and nitrogen storage and microbial biomass after grazing exclusion in semi-arid grasslands of Inner Mongolia. Ecol Eng. 73, 395, 2014.

8. LAGOMARSINO A., BENEDETTI A., MARINARI S., POMPILI L., MOSCATELLI M.C., ROGGERO P.P., LAI R., LEDDA L., GREGO S. Soil organic C variability and microbial functions in a Mediterranean agro-forest ecosystem. Biol. Fert. Soils 47 (3), 283, 2011.

9. WOLINSKA A., KUZNIAR A., ZIELENKIEWICZ U., BANACH A., BLASZCZYK M. Indicators of arable soils fatigue - Bacterial families and genera: A metagenomic approach. Ecol. Ind. 93, 490, 2018.

10. LIN Z., LI Y., TANG C., LUO Y., FU W., CAI X., LI Y., YUE T., JIANG P., HU S., CHANG S.X. Converting natural evergreen broadleaf forests to intensively managed moso bamboo plantations affects the pool size and stability of soil organic carbon and enzyme activities. Biol Fert Soils 54 (4), 1, 2018.

11. JANGID K., WILLIAMS M.A., FRANZLUEBBERS A.J., SCHMIDT T.M., COLEMAN D.C., WHITMAN W.B. Land-use history has a stronger impact on soil microbial community composition than aboveground vegetation and soil properties. Soil Biol. Biochem. 43, 2184, 2011.

12. BRANT J.B., MYROLD D.D., SULZMAN E.W. Root controls on soil microbial community structure in forest soils. Oecologia 148, 650,2006.

13. TRASAR-CEPEDA C, LEIRÓS M C, GIL-SOTRES F. Hydrolytic enzyme activities in agricultural and forest soils. Some implications for their use as indicators of soil quality. Soil Biol Biochem. 40, 2146, 2008.

14. NOURBAKHSH F. Decoupling of soil biological properties by deforestation. Agr Ecosyst Environ. 121 (4), 435, 2007.

15. YIN C., KENNETHL J., DALLASE P., GARRETT K.A., HULBERT S.H., PAULITZ T.C. Members of soil bacterial communities sensitive to tillage and crop rotation. Soil Biol. Biochem. 42, 2111, 2010.

16. BASTIDA F., ZSOLNAY A., HERNÁNDEZ T., GARCIA C. Past, present and future of soil quality indices: A biological perspective. Geoderma 147, 159, 2008.

17. AVERILL C., HAWKES C.V. Ectomycorrhizal fungi slow soil carbon cycling. Ecol. Lett. 19 (8), 937, 2016.

18. BRAY S.R., KITAJIMA K., MACK M.C. Temporal dynamics of microbial communities on decomposing leaf litter of 10 plant species in relation to decomposition rate. Soil Biol. Biochem. 49, 30, 2012.

19. NELSON M.B., MARTINY A.C., MARTINY J.B.H. Global biogeography of microbial nitrogen-cycling traits in soil. Proc Natl Acad Sci U S A. 113 (29), 8033, 2016.

20. BERG G. Plant-microbe interactions promoting plant growth and health: perspectives for controlled use of microorganisms in agriculture. Appl. Microbiol. Biot. 84, $11,2009$.

21. WOLINSKA A., GORNIAK D., ZIELENKIEWICZ U., GORYLUK-SALMONWICZ A., KUZNIAR A., STEPNIEWSKA Z., BLASZCZYK M. Microbial biodiversity in arable soils is affected by agricultural practices. Int. Agrophys. 31(2), 259, 2017.

22. SHI Y., GROGAN P., SUN H., XIONG J.B., YANG Y.F., ZHOU J.Z., CHU H.Y. Multi-scale variability analysis reveals the importance of spatial distance in shaping Arctic soil microbial functional communities. Soil Biol. Biochem. 86, 126, 2015. 
23. CREAMER R.E., HANNULA S.E., LEEUWEN J.P.V., STONE D., RUTGERS M., SCHMELZ R.M., DE RUITER P.C., HENDRIKSEN N.B., BOLGER T., BOUFFAUD M.L., BUEE M., CARVALHO F., COSTA D., DIRILGEN T, FRANCISCO R., GRIFFITHS B.S., GRIFFITHS R., MARTIN F., DA SILVA P.M., MENDES S., MORAIS P.V., PEREIRA C., PHILIPPOT L., PLASSART P., REDECKERP D., RÖMBKE J., SOUSA J.P., WOUTERSE M., LEMANCEAU P. Ecological network analysis reveals the inter-connection between soil biodiversity and ecosystem function as affected by land use across Europe. Appl Soil Ecol. 97 (11), 112, 2016.

24. DING G.C., PICENO Y.M., HEUER H, WEINERT N., DOHRMANN A.B., CARRILLO A., ANDERSEN G.L., CASTELLANOS T., TEBBE C.C.SMALLA K. Changes of Soil bacterial diversity as a consequence of agricultural land Use in a semi-arid ecosystem. Plos One 8, e59497, 2013.

25. WOLINSKA A., REKOSZ-BURLAGA H., GORYLUKSALMONOWICZ A., BLASZCZYK M., STOPNIEWSKA Z. Bacterial abundance and dehydrogenase activity in selected agricultural soils from Lublin region. Pol. J. Environ. Stud. 24 (6), 2677, 2015.

26. KRASHEVSKA V., MALYSHEVA E., KLARNER B., MAZEI Y., MARAUN M., WIDYASTUTI R., SCHEU S. Micro-decomposer communities and decomposition processes in tropical lowlands as affected by land use and litter type. Oecologia 187 (1), 1, 2018.

27. CAO C., ZHANG Y., QIAN W., LIANG C., WANG C., TAO, S. Land-use changes influence soil bacterial communities in a meadow grassland in Northeast China. Solid Earth, 8 (5), 1119, 2017.

28. GOSS-SOUZA D, MENDES L.W., BORGES C.D., BARETTA D, TSAI S.M., RODRIGUES J.L.M. Soil microbial community dynamics and assembly under longterm land use change. FEMS Microbiol Ecol. 93 (10), 1, 2017.

29. JESUS E.D.C., MARSH T.L., TIEDJE J.M., MOREIRA F.M.D.S. Changes in land use alter the structure of bacterial communities in Western Amazon soils. Isme J. 3 (9), 1004,2009.

30. LAGERLÖF J., ADOLFSSON L., BÖRJESSON G., EHLERS K., VINYOLES G.P., SUNDH I. Land-use intensification and agroforestry in the Kenyan highland: Impacts on soil microbial community composition and functional capacity. Appl. Soil Ecol. 82 (82), 93, 2014.

31. LYNN T.M., LIU Q., HU Y., YUAN H., WU X., KHAI A.A., WU J., GE T. Influence of land use on bacterial and archaeal diversity and community structures in three natural ecosystems and one agricultural soil. Arch Microbiol. 199 (5), 1,2017.

32. BALDRIAN P., KOLARIK M., STURSOVA M., KOPECKY J., VALASKOVA V., VETROVSKY T., ZIFCAKOVA L., SNAJDR J., RIDL J., VLCEK C, VORISKOVA J. Active and total microbial communities in forest soil are largely different and highly stratified during decomposition. ISME J. 6, 248,2012.

33. LIN Y.T., KAMLESH J., WILLIAMB W., DAVIDC C., CHIH-YU C. Soil bacterial communities in native and regenerated perhumid montane forests. Appl. Soil Ecol. 47 (2), 111, 2011

34. ELSAS J.D.V., BOERSMA F.G.H. A review of molecular methods to study the microbiota of soil and the mycosphere.Eur. J Soil Biol. 47 (2), 77, 2011.

35. LOUCA S., PARFREY L.W., DOEBELI M. Decoupling function and taxonomy in the global ocean microbiome. Science 353 (6305), 1272, 2016.
36. XU Z., MALMER D., LANGILLE M.G.,WAY S.F., KNIGHT R. Which is more important for classifying microbial communities: who's there or what they can do? ISME J 8 (12), 2357, 2014.

37. LANGILLE M.G.I., ZANEVELD J., CAPORASO J.G., MCDONALD D., KNIGHTS D., REYES J.A., CLEMENTE J.C., BURKEPILE D.E., VEGA THURBER R.L., KNIGHT R. BEIKO R.G., HUTTENHOWER C. Predictive functional profiling of microbial communities using 16S rRNA marker gene sequences. Nat Biotechnol. 31 (9), 814, 2013.

38. ASSHAUER K.P., WEMHEUER B., DANIEL R., MEINICKE P. Tax4Fun: predicting functional profiles from metagenomic 16S rRNA data. Bioinformatics 31 (17), 2882, 2015

39. SARAH H., FRANZISKA W., BERND W., DANIEL R. Effects of fertilization and sampling time on composition and diversity of entire and active bacterial communities in German grassland soils. Plos One 10 (12), e0145575, 2015.

40. KAISER K., WEMHEUER B., KOROLKOW V., WEMHEUER F., NACKE H., SCHÖNING I., SCHRUMPF M., DANIELA R. Driving forces of soil bacterial community structure, diversity, and function in temperate grasslands and forests. Sci. Rep. 6, 33696, 2016.

41. BANERJEE, S. Network analysis reveals functional redundancy and keystone taxa amongst bacterial and fungal communities during organic matter decomposition in an arable soil. Soil Biol. Biochem. 97, 188, 2016.

42. TEAM R.D.C. R: a language and environment for statistical computing. R Foundation for Statistical Computing, R Foundation for Statistical Computing, Vienna, Austria. Computing 14, 2, 2009.

43. LOZUPONE C.A., HAMADY M., KELLEY S.T., KNIGHT R. Quantitative and qualitative beta diversity measures lead to different insights into factors that structure microbial communities. Appl Environ Microbiol. 73, 1576,2007.

44. STOREY J.D., TAYLOR J.E., SIEGMUND D. Strong control, conservative point estimation and simultaneous conservative consistency of false discovery rates: a unified approach. J. R. Stat. Soc. B. 66 (1), 187, 2004.

45. BATLLE-AGUILAR J., BROVELLI A., PORPORATO A.M., BARRY D.A. Modelling soil carbon and nitrogen cycles during land use change. A review. Agron. Sustain. Dev. 31 (2), 251,2011.

46. ELSER J.J., ANDERSEN T., BARON J.S., BERGSTRÖM A.K, JANSSON M., KYLE M., NYDICK K.R. STEGER L., HESSEN D.O. Shifts in lake N: P stoichiometry and nutrient limitation driven by atmospheric nitrogen deposition. Science 326(5954), 835,2009.

47. WEN Z.Z., HONG L.X., ZHI M.L., LI, J. Soil degradation and restoration as affected by land use change in the semiarid Bashang area, northern China. Catena 59, 173, 2005.

48. GUO L.B., GIFFORD R.M. Soil carbon stocks and land use change: a meta analysis. Glob Chang Biol. 8(4), 345,2010

49. TATE K.R, SCOTT N.A, SAGGAR S., GILTRAP D.J., BAISDEN W.T., NEWSOME P.F., TROTTER C.M., WILDE R.H. Land-use change alters New Zealand's terrestrial carbon budget: uncertainties associated with estimates of soil carbon change between 1990-2000. Tellus B 55 (2), 364,2010.

50. GRUNZWEIG J.M., SPARROW S.D., YAKIR D., CHAPIN F.S. Impact of agricultural land-use change on 
carbon storage in boreal Alaska. Glob Chang Biol. 10 (4), 452,2010

51. CAI Z.Q., ZHANG Y.H., YANG C., WANG S. Land-use type strongly shapes community composition, but not always diversity of soil microbes in tropical China. Catena 165, 369, 2018

52. ROSCOE R, BUURMAN P. Tillage effects on soil organic matter in density fractions of a Cerrado Oxisol. Soil Till Res. 70 (2), 107, 2003.

53. XU Q, JIANG P, XU Z. Soil microbial functional diversity under intensively managed bamboo plantations in southern China. J Soil Sediments. 8 (3), 177, 2008.

54. LEWIS T, SMITH T.E, HOGG B, SWIFT S., VERSTRATEN L., BRYANT P., WEHR J.B., NEIL T., MENZIES N., DALAL R.C. Conversion of sub-tropical native vegetation to introduced conifer forest: Impacts on below-ground and above-ground carbon pools. Forest Ecol. Manag. 370, 65,2016.

55. XIONG H.F., WANG Y.H. Spatial variability of soil nutrients in wetland of Liangzi Lake. Plant Nutrition and Fertilizer Science 11 (5), 584, 2005.

56. YANG Y., CHEN G., PENG L., HUANG R., CHEN Y., HE Z. Fine root distribution, seasonal pattern and production in a native forest and monoculture plantations in subtropical China. Acta Ecologica Sinica 23 (9), 1719, 2003.

57. LAGANIÈRE J., PARÉ D., BERGERON Y., CHEN H.Y.H., BRASSARD B.W., CAVARD X. Stability of soil carbon stocks varies with forest composition in the Canadian Boreal Biome. Ecosystems 16 (5), 852, 2013.

58. SCHRIJVER A.D., FRENNE P.D., STAELENS J., VERSTRAETEN G., MUYS B., VESTERDAL L., WUYTS K., NEVEL L.V., SCHELFHOUT S., DE NEVE S., VERHEYEN K. Tree species traits cause divergence in soil acidification during four decades of postagricultural forest development. Global Change Biol. 18 (3), 1127, 2012.

59. PRESCOTT C.E., ZABEK L.M., STALEY C.L., KABZEMS R. Decomposition of broadleaf and needle litter in forests of British Columbia: influences of litter type, forest type, and litter mixtures. Can J Forest Res. 30, 1742, 2000.

60. YANG X.Q., HAN Y.Z. Spatial variations of soil organic carbon and nitrogen of forest land in Guandi Mountain. Forest Research 24 (2), 223, 2011.

61. ZHANG X., HU B.X., REN H., ZHANG J. Composition and functional diversity of microbial community across a mangrove-inhabited mudflat as revealed by $16 \mathrm{~S}$ rDNA gene sequences. Sci Total Environ. 633, 518, 2018.

62. BRACKIN R., ROBINSON N., LAKSHMANAN P., SCHMIDT S. Microbial function in adjacent subtropical forest and agricultural soil. Soil Biol Biochem. 57 (3), 68, 2013.

63. TIAN Q., TANIGUCHI T., SHI W.Y., LI G.Q., YAMANAKA N., DU S. Land-use types and soil chemical properties influence soil microbial communities in the semiarid Loess Plateau region in China. Sci Rep. 7, 45289, 2017.

64. LIN Y.T., HU H.W., WHITMAN W.B., COLEMAN D.C., CHIU C.Y. Comparison of soil bacterial communities in a natural hardwood forest and coniferous plantations in Perhumid Subtropical Low Mountains. Bot Stud. 55, 31, 2014.

65. KUBARTOVÁ A., MOUKOUMI J., BÉGUIRISTAIN T., RANGER J., BERTHELIN J. Microbial diversity during cellulose decomposition in different forest stands:
I. microbial communities and environmental conditions. Microb Ecol. 54 (3), 393, 2007.

66. FIERER N., LAUBER C.L., RAMIREZ K.S. ZANEVELD J., BRADFORD M.A., KNIGHT R. Comparative metagenomic, phylogenetic and physiological analyses of soil microbial communities across nitrogen gradients. ISME J. 6 (5), 1007, 2012

67. MAIA S.M.F., OGLE S.M., CERRI C.E.P., CERRI C. Soil organic carbon stock change due to land use activity along the agricultural frontier of the southwestern Amazon, Brazil, between 1970 and 2002. Glob. Change Biol. 16 (10), 2775, 2010.

68. JENKINS J.R., VIGER M., ARNOLD E.C., HARRIS Z.M., VENTURA M., MIGLIETTA F., CYRIL G., EDWARDS R.J., RUMPEL C., FORNASIER F. Biochar alters the soil microbiome and soil function: results of next-generation amplicon sequencing across Europe. GCB Bioenergy 9 (3), 591, 2017.

69. PENG M., JIA H., WANG Q. The Effect of Land Use on Bacterial Communities in Saline-Alkali Soil. Curr Microbiol. 74, 325, 2017.

70. LEFF J.W., JONES S.E., PROBER S.M., BARBERÁN A., BORER E.T., FIRN J.L., HARPOLE W.S., HOBBIE S.E., HOFMOCKEL K.S., KNOPS J.M., MCCULLLEY R.L., LA P.K., RISCH A.C., SEABLOOM E.W., SCHUTZ M., STEENBOCK C., STEVENS C.J., FIERER N. Consistent responses of soil microbial communities to elevated nutrient inputs in grasslands across the globe. Proc Natl Acad Sci U S A. 112 (35), 10967, 2015.

71. WEI H., PENG C., YANG B., SONG H.X., LI Q., JIANG L., WEI G., WANG K.F., WANG H., LIU, S.R., LIU X.J., CHEN D.X., LI Y.D., WANG M. Contrasting soil bacterial community, diversity, and function in two forests in China. Front Microbiol. 9, 1693, 2018.

72. TOLLI J., KING G.M. Diversity and structure of bacterial chemolithotrophic communities in Pine forest and agroecosystem soils. Appl Environ Microbiol. 71 (12), 8411,2006

73. YOON S., CRUZ-GARCÍA C., SANFORD R., RITALAHTI K.M., LÖFFLER F.E. Denitrification versus respiratory ammonification: environmental controls of two competing dissimilatory $\mathrm{NO}_{3}(-) / \mathrm{NO}_{2}(-)$ reduction pathways in Shewanella loihica strain PV-4. ISME J. 9 (5), 1093, 2014.

74. JOHNSON F.J.M., REICOSKY D.C., ALLMARAS R.R., SAUER T.J., VENTEREA R.T., JELL C.J. Greenhouse gas contributions and mitigation potential of agriculture in the central USA. Soil Till. Res. 83 (1), 73, 2005.

75. LAMBIN E.F., MEYFROIDT P. Global land use change, economic globalization, and the looming land scarcity. Proc Natl Acad Sci U S A. 108 (9), 3465, 2011.

76. MOORE N., ALAGARSWAMY G., PIJANOWSKI B., ALAGARSWAMY G., LOFGREN B.M., OLSON J.M., ANDRESEN J., YANDA P., QI J.G. East African food security as influenced by future climate change and land use change at local to regional scales. Climatic Change $\mathbf{1 1 0}$ (3-4), 823,2012.

77. QIU L., WEI X.R., ZHANG X.C., CHENG J.M., GALE W.J., GUO C., LONG T. Soil organic carbon losses due to land use change in a semiarid grassland. Plant Soil 355 (1-2), 299, 2012.

78. LAMMEL D.R., FEIGL B.J., CERRI C.C., NÜSSLEIN K. Specific microbial gene abundances and soil parameters contribute to $\mathrm{C}, \mathrm{N}$, and greenhouse gas process rates after land use change in Southern Amazonian Soils. Front microbial.6, 1057, 2015. 
79. SHI W., YAO H., BOWMAN D. Soil microbial biomass, activity and nitrogen transformations in a turfgrass chronosequence. Soil Biol. Biochem. 38 (2), 311, 2006.

80. PANDEY C.B., SINGH G.B, SINGH S.K, SINGH R.K. Soil nitrogen and microbial biomass carbon dynamics in native forests and derived agricultural land uses in a humid tropical climate of India. Plant soil 333 (1-2), 453, 2010.

81. SANTORO A.E., FRANCIS C.A., DE SIEYES N.R.D., BOEHM A.B. Shifts in the relative abundance of ammoniaoxidizing bacteria and archaea across physicochemical gradients in a subterranean estuary. Environ Microbiol. 10, 1068, 2010.

82. WALLENSTEIN M.D., MYROLD D.D., VOYTEK F.M. Environmental controls on denitrifying communities and denitrification rates: Insights from Molecular Methods. Ecol Appl. 16 (6), 2143, 2006.

83. CHEN Z., YUAN H., WU J., WEI W. Activity and composition of the denitrifying bacterial community respond differently to long-term fertilization. Acta Ecologica Sinica 71 (12), 8335, 2009.

84. RISGAARD-PETERSEN N., MEYER R.L., REVSBECH N.P. Denitrification and anaerobic ammonium oxidation in sediments: effects of microphytobenthos and $\mathrm{NO}_{3}{ }^{-}$. Aquat Microb Ecol. 40 (1), 67, 2005.

85. PETERSEN D.G., BLAZEWICZ S.J., FIRESTONE M., HERMAN D.J., TURETSKY M., WALDROP M. Abundance of microbial genes associated with nitrogen cycling as indices of biogeochemical process rates across a vegetation gradient in Alaska. Environ Microbiol. 14 (4), 993, 2012.

86. XU Y.B., CAI Z.C. Denitrification characteristics of subtropical soils in China affected by soil parent material and land use. Eur. J Soil Sci. 58 (6), 1293,2010. 
